\title{
New approach for investigation of reinforcement in polymer nanocomposites using oscillatory shear flow data
}

\begin{abstract}
MilAN KRACALIK - Institute of Polymer Science, Johannes Kepler University Linz - Milan.Kracalik@jku.at Érkezett: 2017. 12. 19. - Received: 19. 12. 2017. - https://doi.org/10.14382/epitoanyag-jsbcm.2018.9
\end{abstract}

\begin{abstract}
Polymer nanocomposites exhibit complex rheological behaviour due to physical and also possibly chemical interactions between individual phases. Up to now, rheology of polymer nanocomposites has been usually described by evaluation of viscosity curve (shear thinning phenomenon), storage modulus curve (formation of secondary plateau) or plotting information about damping behaviour (e.g. Van Gurp-Palmen-plot, Cole-Cole plot). On the contrary to evaluation of damping behaviour, new approach - based on evaluation of rigidity behaviour - was tested, where the values of $\cot \delta$ were calculated and called as "storage factor", analogically to loss factor. Afterwards, values of storage factor were integrated over specific frequency range and called as "cumulative storage factor". In this contribution, LDPE-ZnO-clay nanocomposites with different polyethylene matrices and dispersion grades (physical networks) have been prepared and characterized by both conventional as well as novel analysis approach. Next to cumulative storage factor, further cumulative rheological parameters like cumulative complex viscosity, cumulative complex modulus or cumulative storage modulus have been introduced.

Keywords: shear flow, oscillatory shear, polymer, clay, nanocomposites

Kulcsszavak: nyírási folyás, változó amplitúdójú nyírás, polimer, agyag, nanokompozitok
\end{abstract}

Prof. Dr. Milan KRACALIK

is assistant professor at the Institute of Polymer Science, Johannes Kepler University Linz. His field of expertise covers in particular polymer rheology, polymer composites and nanocomposites, polymer recycling, study of structure-properties relationship in polymer materials and management associated with technological processes and products. He studied Technology \& Management at the Brno University of Technology, Czech Republic (MSc.: 2000), at Tomas Bata University in Zlin and Institute of Macromolecular Chemistry, Academy of Sciences of the Czech Republic

(Ph.D.: 2006) associated with praxis in marketing department of Podravka-Lagris Inc., Czech Republic. Between 2006 and 2012 he was post-doc researcher \& project leader at the Department of Polymer Engineering and Science of the University of Leoben, Austria. Between 2012 and 2014 he was research manager at the Department Research and Development of the ISOVOLTAIC AG, Austria. He has also lectured on Technology \& Management at several European universities such as Albert Ludwigs University Freiburg, Budapest University of Technology and Economics, Chemical Research Centre / Hungarian Academy of Sciences, University of Zagreb and Department of Technical Sciences / Croatian Academy of Sciences and Art.

\section{Introduction}

Nanocomposites using organically modified clays have been intensively investigated due to enhancement of processing as well as application properties of polymer matrix. Using nanoparticles is an interesting way for preparation of tailored materials, possibly also with recycled polymers. The enhancement of material properties because of nanoparticles addition has usually been analyzed using a combination of morphological (X-ray diffraction (XRD), transmission electron microscopy (TEM)), mechanical (tensile testing) and rheological (rotational rheometry) measurements. Using 2-5\% of organoclay, significant enhancement of material properties has been reported: higher elastic modulus, tensile strength, thermal resistivity, lower gas and liquid permeability, reduced flammability and improved rheological properties (increased melt strength) compared to the unfilled polymer matrix. High reinforcement due to addition of the layered silicates results from their large surface area (in the case of montmorillonite $700-800 \mathrm{~m} 2 / \mathrm{g}$ ) [31, 33, 38]. In the case of highly dispersed systems, a three dimensional physical network is achieved, formed due to interactions between silicate platelets and the polymer chains. This phenomenon can be investigated by analysis of the melt elasticity using rotational rheometry [1-47]. These studies are mainly based on evaluation of viscosity curve shape (shear thinning phenomenon), storage modulus curve at low frequencies (formation of secondary plateau), phase homogeneity (Cole-Cole plot) or plotting information about damping behaviour (e.g. Van Gurp-Palmen-plot, comparison of loss factor $\tan \delta$ ). In order to enable simple comparison of nanocomposites reinforcement in the shear flow, new way to analyze data of the shear flow has been tested [18]. The storage modulus $G^{\prime}$ reflects the elastic part while the loss modulus gives information about the viscous part of the dynamic shear flow. The relation of $\mathrm{G}^{\prime \prime} / \mathrm{G}^{\prime}$ is defined as $\tan \delta$ and describes damping behaviour of the polymer system. On the contrary, to our knowledge, the $G^{\prime} / G^{\prime \prime}$ ratio $(\cot \delta)$ has not been used for rheological evaluation of nanocomposites up to now. Compared to $\tan \delta$ (loss factor), $\cot \delta$ (named as storage factor, SF) reflects melt rigidity, which can be associated with reinforcement effect of nanostructured filler (combination of chain elasticity with silicate layers rigidity in the polymer melt). In order to reduce the values of storage factor to one representative magnitude for one nanocomposite sample, $G^{\prime}$ as well as $G^{\prime \prime}$ curves have been integrated over the measured frequency range as following:

$$
C S F=\int_{0.1 \mathrm{rad} / \mathrm{s}}^{628 \mathrm{rad} / \mathrm{s}} G^{\prime} / \int_{0.1 \mathrm{rad} / \mathrm{s}}^{628 \mathrm{rad} / \mathrm{s}} G^{\prime \prime}
$$

In this way, cumulative storage factor (CSF) and some further cumulative rheological parameters (e.g. cumulative complex viscosity $\mathrm{CCV}$, cumulative complex modulus $\mathrm{CCM}$, cumulative storage modulus CSM) were introduced [16]. It was proven that values of CSF can be correlated with values of melt strength, i.e. the reinforcement in polymer nanocomposites can be assessed and compared in both, shear as well in elongational flow [18]. In this paper, LDPE-ZnO-clay nanocomposites with different dispersion grades (physical networks) are reported. It is shown that nanoscaled $\mathrm{ZnO}$ can be used not only as UV stabilizer but also as reinforcement and dispersion agent, respectively. The obtained data is analysed in this paper using typical rheological approaches as well as cumulative rheological parameters like CSF or CCV. 


\section{Materials}

Two low-density polyethylene grades: low melt viscosity CA9150 (MFR $\left(190^{\circ} \mathrm{C} / 2.16 \mathrm{~kg}\right): 15 \mathrm{~g} / 10 \mathrm{~min}$, Borealis Inc., Linz, Austria) and high melt viscosity Lupolen 2420 D (MFR $\left(190^{\circ} \mathrm{C} / 2.16 \mathrm{~kg}\right): 0.25 \mathrm{~g} / 10 \mathrm{~min}$, LyondellBasell Industries Inc., Rotterdam, Netherlands) have been used for the preparation of nanocomposites. The used nanoclay Cloisite20 (Cl20) as well as masterbatch with nano-scaled $\mathrm{ZnO}$ (Nanobyk, dispersion of $30 \%$ zinc oxide nanoparticles in low-molecular weight polyethylene) were supplied by BYK-Chemie Ltd, Wesel, Germany / POLYchem Ltd, Markt Allhau, Austria, respectively.

\section{Experimental}

Nanocomposites have been prepared using laboratory compounder MiniLab II Haake Rheomex CTW5 (Thermo Fisher Scientific, Germany). Performance of 8 different compositions (pure PE matrices, 5wt.\% of $\mathrm{Cl} 20$, 5wt.\% of $\mathrm{ZnO}$, 2.5/2.5 wt.\% of $\mathrm{Cl} 20 / \mathrm{ZnO}$ ) have been compared. Rheological properties in the shear flow were analyzed using a Physica MCR 502 rheometer (Anton Paar Ltd., Graz, Austria) with the coneplate geometry of $25 \mathrm{~mm}$ diameter and measuring gap of $43 \mu \mathrm{m}$.

\section{Results and discussion}

The nanocomposites structure has been usually assessed by analysis of viscosity curve (shear-thinning effect) in combination with evaluation of the storage modulus curve $\left(G^{\prime}\right.$ secondary plateau). In Fig. 1.a and 1.b, magnitudes of complex viscosity for nanocomposites based on both LDPE matrices in dependency on angular frequency have been plotted. Addition of nanoparticles to CA9150 resulted to significant differences in the viscosity of mixtures. On the other hand, no substantial differences between viscosity values of systems filled in Lupolen (Fig. 1.b) can be seen. This is because dispersion process of polymer nanocomposites based on layered silicates (delamination) requires enough chain mobility so that molten polymer chains are able to penetrate into interlayer space of silicate. In high viscosity / high melt strength polymers, chain mobility is rather reduced and, consequently, it is difficult to achieve high dispersion grade. This is confirmed in Figs. 1.a, 1.b, 2.a, 2.b, where mixtures based on Lupolen showed typical pseudoplastic behaviour (Fig. 1.b) with viscoelastic feature (Fig. 2.b), while 2 nanocomposites based on CA9150 (5\% Cl20, 2.5\% $\mathrm{Cl} 20 / 2.5 \% \mathrm{ZnO})$ revealed pronounced shear-thinning behaviour (Fig. 1.a) concomitant with rubber-like behaviour at low frequencies (Fig. 2.a), indicating high dispersion grade. Lower viscosity values of nanocomposites with $5 \% \mathrm{ZnO}$ and 2.5\% $\mathrm{Cl} 20 / 2.5 \% \mathrm{ZnO}$ comparing with pure LDPE matrices (Fig. 1a, 1b) can be explained by significantly lower viscosity of $\mathrm{PE}$ matrix used for preparation of $\mathrm{ZnO}$ masterbatch. It was not possible to measure MFR value of $\mathrm{ZnO}$ masterbatch at $190^{\circ} \mathrm{C} / 2.16 \mathrm{~kg}$, but the value $404 \mathrm{~g} / 10 \mathrm{~min}$ measured by 100 ${ }^{\circ} \mathrm{C} / 2,16 \mathrm{~kg}$ confirms a significant "dilution" effect in used LDPE matrices. The higher admixture of $\mathrm{ZnO}$ masterbatch to CA9150 or Lupolen matrix results to higher "dilution" of CA9150 or Lupolen matrix, respectively, i.e. the average molecular weight in such polymer blends will be lowered.
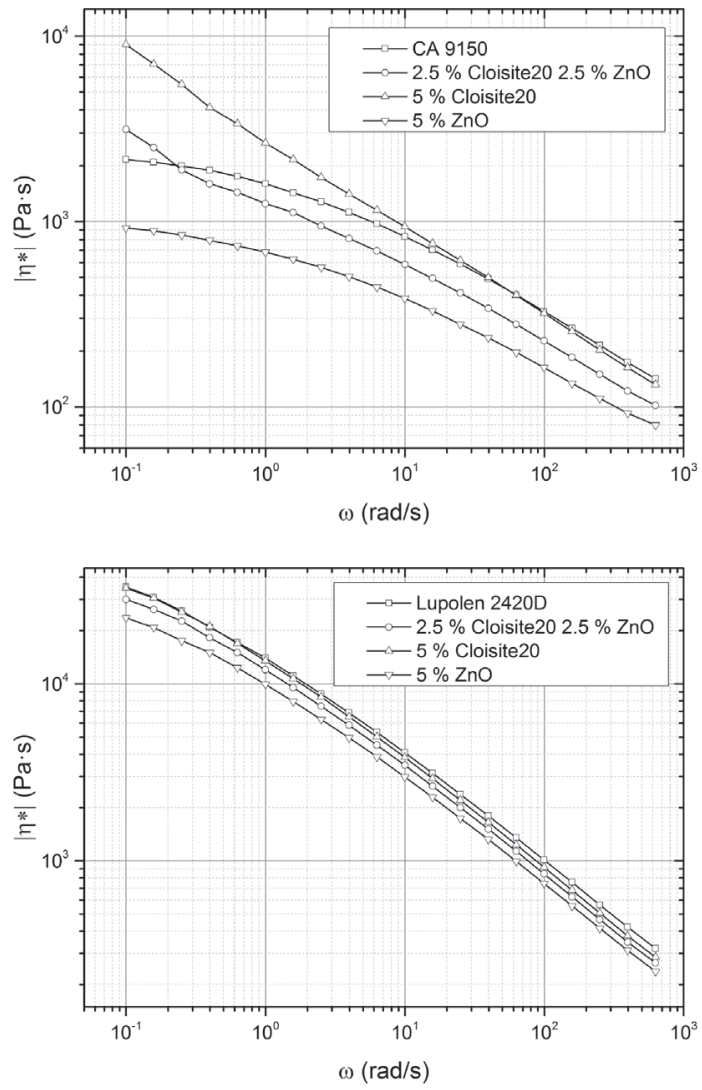

Fig. 1. Complex viscosity of nanocomposites

1.ábra Nanokompozitok komplex viszkozitása
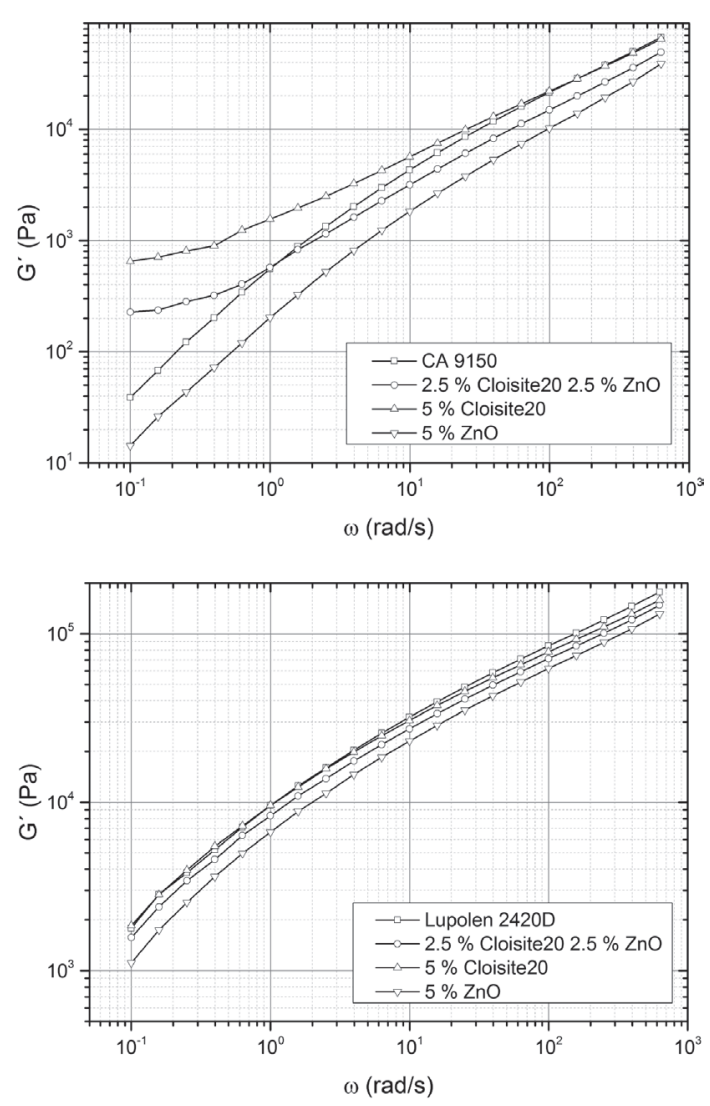

Fig. 2. Storage modulus of nanocomposites

2. ábra Nanokompozitok tárolási modulusa 
The van Gurp-Palmen (vGP) plot as a dependency of loss angle $\delta$ on complex modulus $\left|\mathrm{G}^{*}\right|$ has been usually used in order to evaluate the topological structures of polymers. The vGP plot is temperature invariant and can be used to check for the time temperature superposition principle [48-52]. In Figs. 3. $a$ and 3.b, this kind of dependency is plotted for prepared samples. For the polymers with rather linear chain structure, a continuous shaped curve has been published. On the contrary, long chain branched (LCB) polymers revealed a developed bump between the $\left|\mathrm{G}^{*}\right|$ minimum and the $90^{\circ}$ plateau [50,51]. As can be seen in Fig. 3.a, systems prepared with $\mathrm{Cl} 20$ and $\mathrm{Cl} 20 / \mathrm{ZnO}$ in CA9150 show topological structure similar to mentioned LCB polymers with even two bumps or peaks $(\mathrm{Cl} 20)$, indicating 3D physical network made of silicate layers and polymer chains. The pure CA9150 matrix and nanocomposite with $5 \% \mathrm{ZnO}$ showed behaviour associated with linear chain structure. It can be seen in Fig. $3 . b$ that Lupolen matrix as well as nanocomposites based on it exhibited continuous shaped curve, i.e. the physical network formed in nanocomposites using Lupolen matrix was rather weak and could not be characterized from vGP plot.
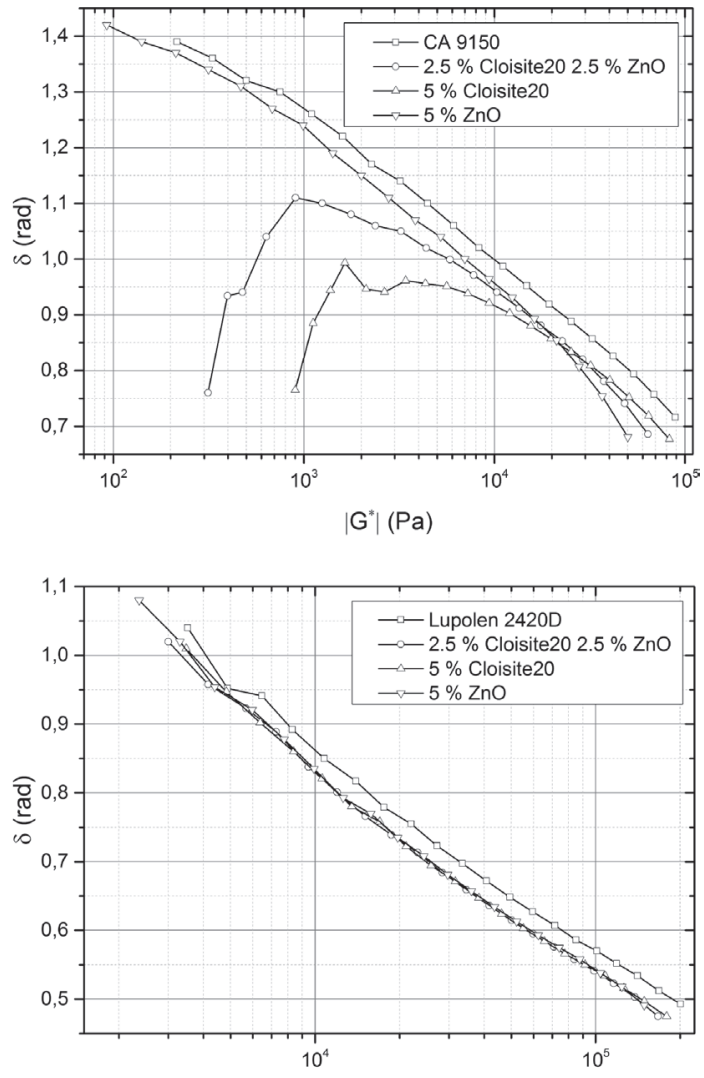

$\left|\mathrm{G}^{*}\right|(\mathrm{Pa})$

Fig. 3. Van Gurp-Palmen plot of nanocomposites

3. ábra Nanokompozitok Van Gurp-Palmen diagramja

In order to provide additional information about viscoelastic damping behaviour of the prepared samples, phase angle $\delta$ in dependency on angular frequency has been plotted (Figs. 4.a and 4.b). The curves for nanocomposites with CA9150 as well as Lupolen matrix are similar to those of vGP plot. Mixtures using CA9150 polymer matrix (Fig. 4.a) confirm formation of differently organized structures (specific combination of agglomerated, delaminated and exfoliated structure in nanocomposites) depending on 3D microstructure. Samples using Lupolen matrix (Fig. 4.b) exhibit similar damping behaviour.
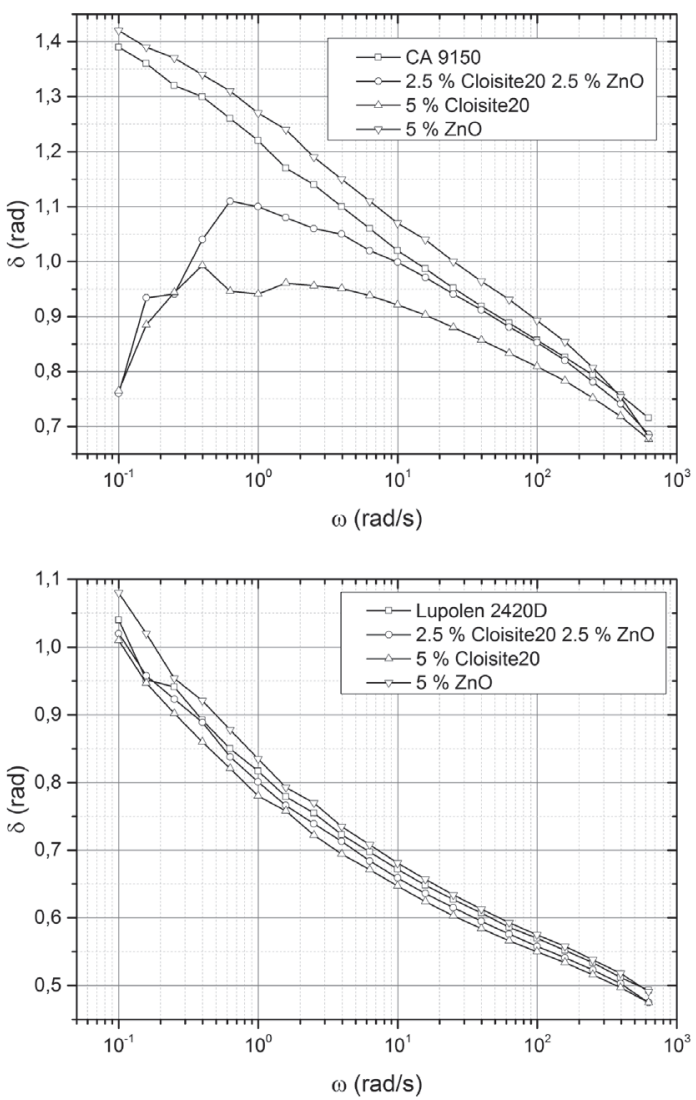

Fig. 4. Phase shift in dependency on angular frequency.

4. ábra Fáziseltolódás a körfrekvencia függvényében

Other approach for description of viscoelastic damping behaviour is "Cole-Cole" figure, where imaginary part of complex viscosity is plotted over the real part. This plot has been usually used to assess miscibility/homogeneity of polymer blends and composites in the way that a smooth, semicircular shape can be interpreted by better compatibility and homogeneity [53, 54]. As shown in Fig. 5.a, the CA9150 matrix and nanocomposite with $5 \% \mathrm{ZnO}$ showed semi-circle shapes, reflecting high homogeneity of the system. However, for the analysis of polymer nanocomposites performance, not only homogeneity but also mechanical reinforcement should be addressed. Using Cole-Cole plot, it seems that systems prepared with $\mathrm{Cl} 20$ and $\mathrm{Cl} 20 / \mathrm{ZnO}$ revealed deviation from semi-circle shape and, therefore, are rather not homogeneous. However, no information about reinforcement level can be obtained from this figure. The Cole-Cole plot for nanocomposites using Lupolen matrix showed semi-circle shapes for all samples and, therefore, it cannot be used for analysis of differencies between pure polymer matrix and filled systems.

Using previously introduced analysis based on "melt rigidity" behaviour $[16,18]$, there is possibility to analyse reinforcement level as result of 3D physical network between polymer chains and filler particles and, consequently, to obtain some 
information hidden in analysis based on damping behaviour (vGP, Cole-Cole plot) or typical evaluation of viscosity or storage modulus curves. The cumulative storage factor plotted over cumulative complex viscosity in Figs. 6.a and 6.b show clearly other trend as trends obtained from figures analysed previously in this paper.
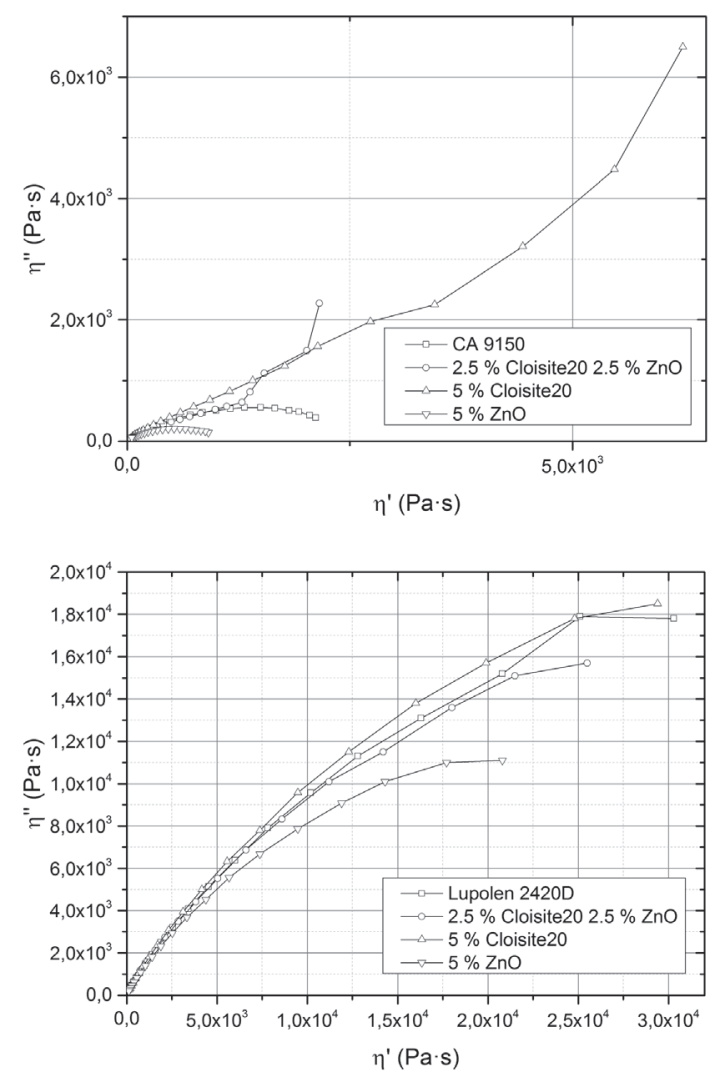

Fig. 5. Cole-Cole plot

5. ábra Cole-Cole diagram

For CA9150 matrix (Fig. 6.a) it can be seen that viscosity value is high, but reinforcement level (comparing to all nanocomposites) is low. Comparing to CA9150, the nanocomposite with $5 \%$ of $\mathrm{ZnO}$ revealed lower value of viscosity (due to admixture of low-viscous PE masterbatch carrier), but higher value of reinforcement, followed by nanocomposite with $2.5 / 2.5$ wt.\% of $\mathrm{Cl} 20 / \mathrm{ZnO}$ and finally followed by nanocomposite with $5 \mathrm{wt} . \%$ of $\mathrm{Cl} 20$ showing the highest reinforcement and approximately same level of viscosity as CA9150 (as in this case, no "dilution" effect was caused). In this way, it was possible to recognize effect of "internal reinforcement" coming from internal friction (change in viscosity coming from mixture of two polyethylenes with different MFR values) - described by CCV - and "external reinforcement" coming from 3D physical network between polymer chains and nanofiller particles - described by CSF. These two effects were not possible to be separated using evaluation methods based on damping behaviour.

It is also interesting to compare the values of CCV of CA9150/ Lupolen matrices and corresponding nanocomposites filled with $5 \%$ of $\mathrm{ZnO}$. It can be clearly seen that dilution effect in low-viscosity matrix (CCV of mixture with $5 \% \mathrm{ZnO}$ is about two-times lower than CCV of CA9150) is much higher than that in high-viscosity matrix (CCV of mixture with $5 \% \mathrm{ZnO}$ is about $25 \%$ lower than CCV of Lupolen).
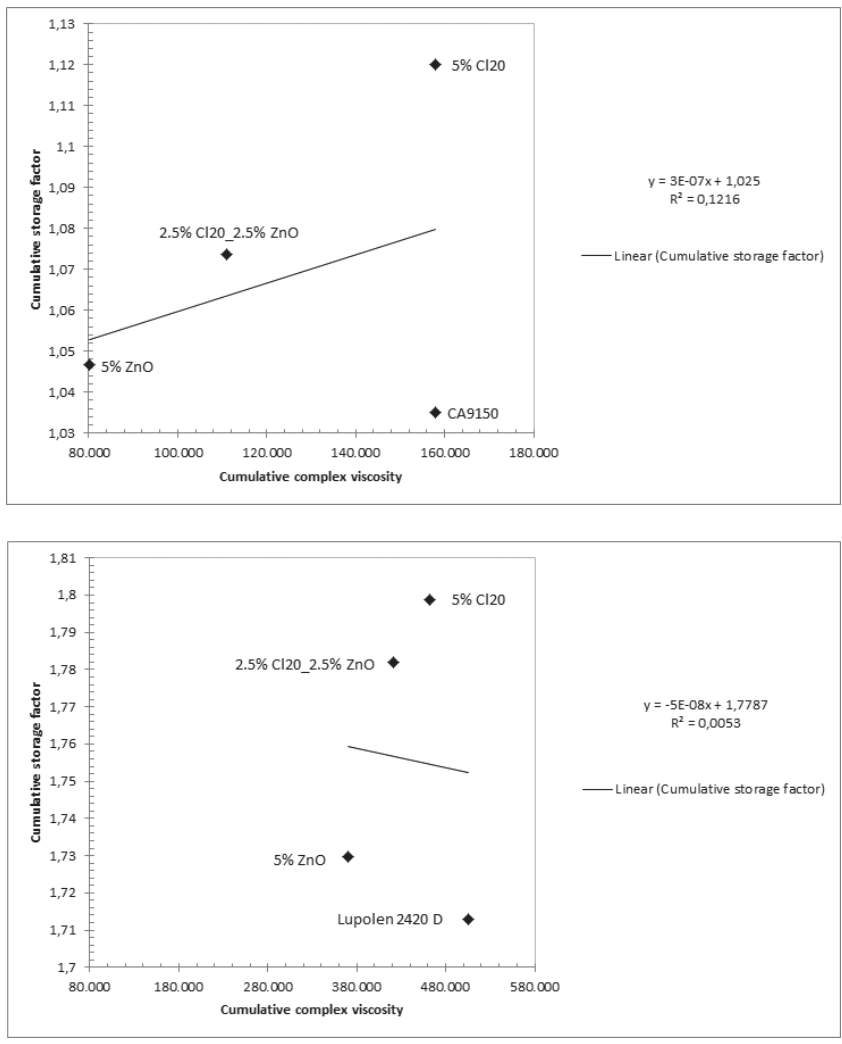

Fig. 6. Cumulative storage factor.

6. ábra Összegzett tárolási tényezö
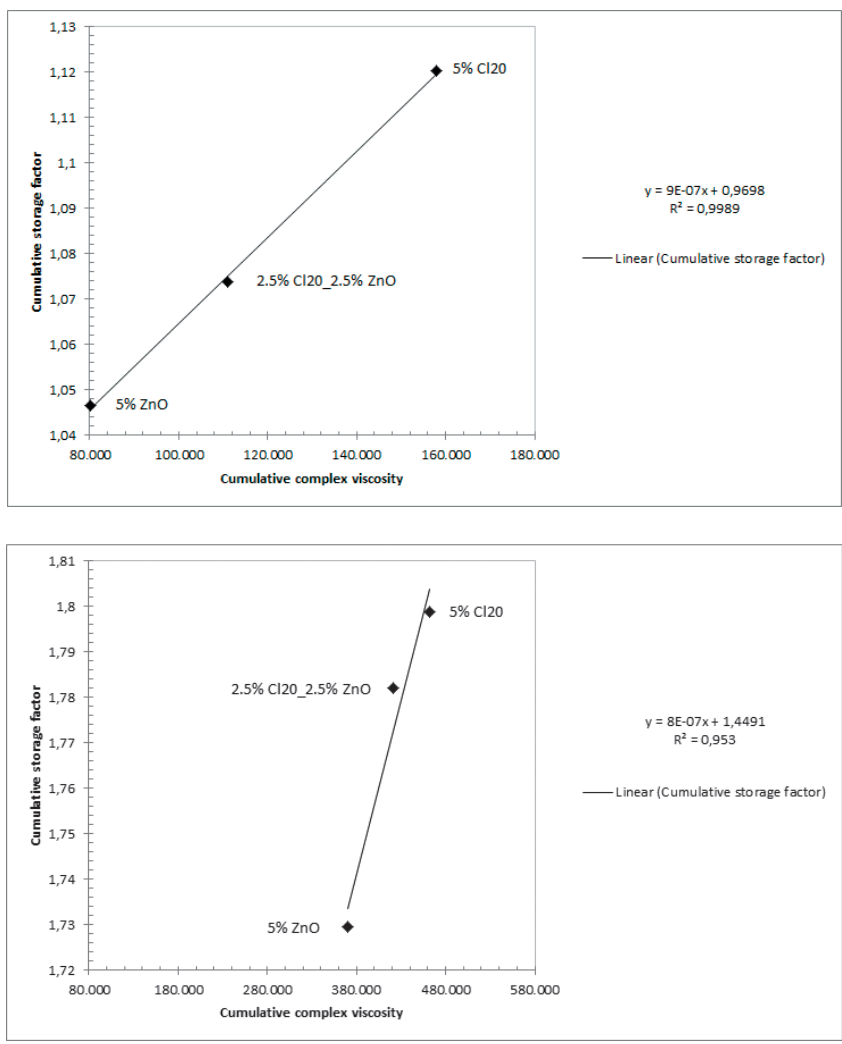

Fig. 7. Cumulative storage factor of nanocomposites without neat matrix 7. ábra Ágyazóanyag mentes nanokompozitok összegzett tárolási tényezője 
Comparing to Fig. 6.a, coefficient of linear regression in Fig. 7.a (without polymer matrix) is very high. It means, if only polymer nanocomposites are compared, there is high correlation between CSF and CCV values, giving possibility to compare previously described "external reinforcement" not only in cases of nanocomposites using one polymer matrix, but also in cases of nanocomposites based on polymer blends. This is proved in Fig. 8, where all nanocomposites using low-viscous CA9150 as well as high-viscous Lupolen are compared in one data set with high correlation coefficient.

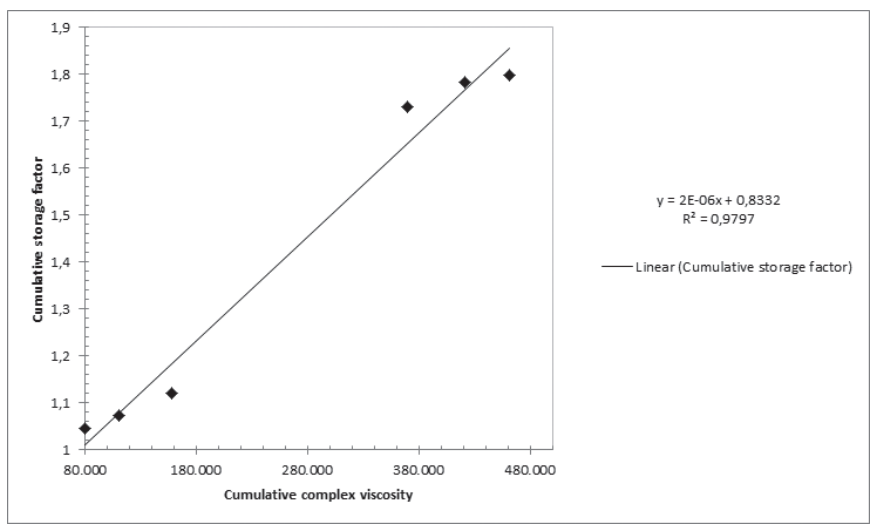

Fig. 8. Cumulative storage factor of nanocomposites with both LDPE matrices 8. ábra LDPE ágyazóanyagú nanokompozitok összegzett tárolási tényezője

\section{Conclusions}

Polymer nanocomposite blends with different melt viscosity polyethylenes and clay/ZnO nanoparticles were prepared and analysed by conventional as well by new rheological approach. Using novel approach based on melt rigidity analysis (cumulative storage factor) the reinforcement caused by $3 \mathrm{D}$ physical network between polymer chains and nanofiller particles could be separated from that coming from internal friction (associated with polymer melt viscosity). In this way, new insight into structure/property relation description of polymer nanocomposites has been introduced.

\section{References}

[1] Abdel-Goad, M. (2011): Rheological characterization of melt compounded polypropylene/clay nanocomposites, Composites Part B 42 (2011) 10441047. https://doi.org/10.1016/j.compositesb.2011.03.025

[2] Aghjeh, M. R. - Asadi, V. - Mehdijabbar, P. - Khonakdar, H. A. - Jafari, S. H. (2015): Application of linear rheology in determination of nanoclay localization in PLA/EVA/Clay nanocomposites: Correlation with microstructure and thermal properties, Composites Part B (2015) 273284. https://doi.org/10.1016/j.compositesb.2015.09.064

[3] Ahmed, J. - Auras, R. - Kijchavengkul, T. - Varshney, S. K. (2012): Rheological, thermal and structural behavior of poly (e-caprolactone) and nanoclay blended films, Journal of Food Engineering (2012) 580-589. https://doi.org/10.1016/j.jfoodeng.2012.03.014

[4] Allahbakhsh, A. - Mazinani, S. - Kalaee, M. R. - Sharif, F. (2013): Cure kinetics and chemorheology of EPDM/graphene oxide nanocomposites, Thermochimica Acta 563 (2013) 22-32. https://doi.org/10.1016/j.tca.2013.04.010

[5] Al-Saleh, M. H. - Sundararaj, U. (2010): Processing-microstructureproperty relationship in conductive polymer nanocomposites, Polymer 51 (2010) 2740-2747. https://doi.org/10.1016/j.polymer.2010.03.022

[6] Al-Samhan, M. - Samuel, J. - Al-Attar, F. - Abraham, G. (2017): Comparative Effects of MMT Clay Modified with Two Different Cationic
Surfactants on the Thermal and Rheological Properties of Polypropylene Nanocomposites, Hindawi (2017). https://doi.org/10.1155/2017/5717968

[7] Anderson, B. J. - Zukoski, C. F. (2010): Rheology and microstructure of polymer nanocomposite melts: Variation of polymer segment-surface interaction, Langmuir 26 (2010) 8709-8720.

https://doi.org/10.1021/la9044573

[8] Ayyer, R. K. - Leonov, A. I. (2004): Comparative rheological studies of polyamide- 6 and its low loaded nanocomposite based on layered silicates, Rheologica Acta 43 (2004) 283-292. https://doi.org/10.1007/s00397-003-0343-6

[9] Block, C. - Watzeels, N. - Rahier, H. - van Mele, B. - van Assche, G. (2011): Rheology of nanocomposites, Journal of thermal analysis and calorimetry 105 (2011) 731-736. https://doi.org/10.1007/s10973-011-1417-9

[10] Cassagnau, P. (2008): Melt rheology of organoclay and fumed silica nanocomposites, Polymer 49 (2008) 2183-2196. https://doi.org/10.1016/j.polymer.2007.12.035

[11] Chambon, F. - Winter, H. H. (1987): Linear viscoelasticity at the gel point of a crosslinking PDMS with imbalanced stoichiometry, Journal of Rheology 31 683-697. https://doi.org/10.1122/1.549955

[12] Chevallier, C. - Becquart, F. - Taha, M. (2013): Polystyrene/polycarbonate blends compatibilization: Morphology, rheological and mechanical properties, Materials Chemistry and Physics (2013) 616-622. https://doi.org/10.1016/j.matchemphys.2013.02.006

[13] Filippone, G. - Carroccio, S. C. - Curcuruto, G. - Passaglia, E. Gamarotti, C. - Dintcheva, N. Tz. (2015): Time-resolved rheology as a tool to monitor the progress of polymer degradation in the melt state Part II: Thermal and thermo-oxidative degradation of polyamide 11/organoclay nanocomposites, Polymer (2015) 102-110. https://doi.org/10.1016/j.polymer.2015.07.042

[14] Ghanbari, A. - Heuzey, M.-C. - Carreau, P. J. - Ton-That, M.-T. (2013): Morphological and rheological properties of PET/clay nanocomposites, Rheologica Acta (2013) 59-74. https://doi.org/10.1007/s00397-012-0667-1

[15] Goffin, A.-L. - Raquez, J. M. - Duquesne, E. - Siqueria, G. - Habibi, Y. - Dufresne, A. - Dubois, P. (2011): Poly(e-caprolactone) based nanocomposites reinforced by surface-grafted cellulose nanowhiskers via extrusion processing: Morphology, rheology, and thermo-mechanical properties, Polymer 52 (2011) 1532-1538. https://doi.org/10.1016/j.polymer.2011.02.004

[16] Kracalik, M. (2015): Rheology of multiphase polymer systems using novel "melt rigidity" evaluation approach, in: AIP Publishing LLC, 2015, p. 40002.

[17] Kracalik, M. - Laske, S. - Holzer, C. (2011): Extensional Rheology as Effective Tool for Characterization of Polymer Nanocomposites, Novel Trends in Rheology IV 1375 (2011). https://doi.org/10.1063/1.3604480

[18] Kracalik, M. - Laske, S. - Witschnigg, A. - Holzer, C. (2011): Elongational and shear flow in polymer-clay nanocomposites measured by on-line extensional and off-line shear rheometry, Rheologica Acta (2011) 937-944. https://doi.org/10.1007/s00397-011-0545-2

[19] Kracalik, M. - Pospisil, L. - Slouf, M. - Mikesova, J. - Sikora, A. - Simonik, J. - Fortelny, I. (2008): Effect of glass fibers on rheology, mechanical properties of recycled thermal and PET, Polymer Composites 29 (2008) 915-921. https://doi.org/10.1002/pc.20467

[20] Kracalik, M. - Pospisil, L. - Slouf, M. - Mikesova, J. - Sikora, A. - Simonik, J. - Fortelny, I. (2008): Recycled poly(ethylene terephthalate) reinforced with basalt fibres: Rheology, structure, and utility properties, Polymer Composites 29 (2008) 437-442. https://doi.org/10.1002/pc.20425

[21] Krishnamoorti, R. - Banik, I. - Xu, L. (2010): Rheology and processing of polymer nanocomposites, Reviews in Chemical Engineering 26 (2010) 354.

[22] Laske, S. - Kracalik, M. - Gschweitl, Michael M. - Feuchter, M. - Maier, G. - Pinter, G. - Thomann, R. - Friesenbichler, W. - Langecker, G. R. (2009): Estimation of Reinforcement in Compatibilized Polypropylene Nanocomposites by Extensional Rheology, Journal of Applied Polymer Science 111 (2009) 2253-2259. https://doi.org/10.1002/app.29163

[23] Laske, S. - Witschnigg, A. - Mattausch, H. - Kracalik, M. - Pinter, G. Feuchter, M. - Maier, G. - Holzer, C. (2012): Determining the ageing of polypropylene nanocomposites using rheological measurements, Applied Rheology (2012). https://doi.org/10.3933/ApplRheol-22-24590 
[24] Le Losq, C. - Neuville, D. R. (2013): Effect of the $\mathrm{Na} / \mathrm{K}$ mixing on the structure and the rheology of tectosilicate silica-rich melts, Chemical Geology 346 (2013) 57-71. https://doi.org/10.1016/j.chemgeo.2012.09.009

[25] Li, J. - Zhou, C. - Wang, G. - Zhao, D. (2003): Study on rheological behavior of polypropylene/clay nanocomposites, J. Appl. Polym. Sci. 89 (2003) 3609-3617. https://doi.org/10.1002/app.12643

[26] Li, Z. - Liu, F. - Xu, G. - Zhang, J. - Chu, C. (2014): A kinetics-controlled coating method to construct 1D attapulgite @ amorphous titanium oxide nanocomposite with high electrorheological activity, Colloid and Polymer Science 292 (2014) 3327-3335. https://doi.org/10.1007/s00396-014-3384-8

[27] Liu, Q. - Chen, D. (2008): Viscoelastic behaviors of poly( $\varepsilon$-caprolactone)/ attapulgite nanocomposites, European Polymer Journal 44 (2008) 20462050. https://doi.org/10.1016/j.eurpolymj.2008.04.035

[28] Miltner, H. E. - Watzeels, N. - Block, C. - Gotzen, N.-A. - van Assche, G. - Borghs, K. - van Durme, K. - van Mele, B. - Bogdanov, B. - Rahier, H. (2010): Qualitative assessment of nanofiller dispersion in poly( $\varepsilon$ caprolactone) nanocomposites by mechanical testing, dynamic rheometry and advanced thermal analysis, European Polymer Journal 46 (2010) 984 996. https://doi.org/10.1016/j.eurpolymj.2010.01.002

[29] Mishra, J. K. - Hwang, K.-J. - Ha, C.-S. (2005): Preparation, mechanical and rheological properties of a thermoplastic polyolefin (TPO)/organoclay nanocomposite with reference to the effect of maleic anhydride modified polypropylene as a compatibilizer, Polymer 46 (2005) 1995-2002. https://doi.org/10.1016/j.polymer.2004.12.044

[30] Nobile, M. R. - Simon, G. P. - Valentino, O. - Morcom, M. (2007): Rheological and Structure Investigation of Melt Mixed Multi-Walled Carbon Nanotube/PE Composites, Macromol. Symp. 247 (2007) 78-87. https://doi.org/10.1002/masy.200750110

[31] Paul, D. R. - Robeson, L. M. (2008): Polymer nanotechnology: Nanocomposites, Polymer 49 (2008) 3187-3204. https://doi.org/10.1016/j.polymer.2008.04.017

[32] Pötschke, P. - Fornes, T. D. - Paul, D. R. (2002): Rheological behavior of multiwalled carbon nanotube/polycarbonate composites, Polymer 43 (2002) 3247-3255. https://doi.org/10.1016/S0032-3861(02)00151-9

[33] Ray, S. S. - Okamoto, K. - Maiti, P. - Okamotoa, M. (2002): New Poly(butylene succinate)/Layered Silicate Nanocomposites: Preparation and Mechanical Properties, Journal of Nanoscience and Nanotechnology 2 (2002) 171-176. https://doi.org/10.1166/jnn.2002.086

[34] Sadeghipour, H. - Ebadi-Dehaghani, H. - Ashouri, D. - Mousavian, S. - Hashemi-Fesharaki, M. - Gahrouei, M. S. (2013): Effects of modified and non-modified clay on the rheological of high density polyethylene, Composites: Part B (2013) 164-171.

https://doi.org/10.1016/j.compositesb.2013.04.010

[35] Samakande, A. - Sanderson, R. D. - Hartmann, P. C. (2009): Rheological properties of RAFT-mediated poly(styrene-co-butyl acrylate)-clay nanocomposites [P(S-co-BA)-PCNs]: Emphasis on the effect of structural parameters on thermo-mechanical and melt flow behaviors, Polymer 50 (2009) 42-49. https://doi.org/10.1016/j.polymer.2008.10.050

[36] Samyn, F. - Bourbigot, S. - Jama, C. - Bellayer, S. - Nazare, S. - Hull, R. Castrovinci, A. - Fina, A. - Camino, G. (2008): Crossed characterisation of polymer-layered silicate (PLS) nanocomposite morphology: TEM, $\mathrm{X}$-ray diffraction, rheology and solid-state nuclear magnetic resonance measurements, European Polymer Journal 44 (2008) 1642-1653. https://doi.org/10.1016/j.eurpolymj.2008.03.021

[37] Százdi, L. - Ábrányi, Á. - Pukánszky, B. - Vancso, J. G. (2006): Morphology Characterization of PP/Clay Nanocomposites Across the Length Scales of the Structural Architecture, Macromol. Mater. Eng. 291 (2006) 858-868. https://doi.org/10.1002/mame.200600026
[38] Thomas, S. - Muller, R. - Abraham, J. (2016): Rheology and Processing of Polymer Nanocomposites, John Wiley \& Sons, Inc, Hoboken, NJ, USA, 2016.

[39] Vermant, J. - Ceccia, S. - Dolgovskij, M. K. - Maffettone, P. L. - Macosko, C. W. (2007): Quantifying dispersion of layered nanocomposites via melt rheology, Journal of Rheology 51 (2007) 429-450. https://doi.org/10.1122/1.2516399

[40] Wagener, R. - Reisinger, T. J. G. (2003): A rheological method to compare the degree of exfoliation of nanocomposites, Polymer 2003 7513-7518. https://doi.org/10.1016/j.polymer.2003.01.001

[41] M. Wang, - X. Fan, - Thitsartarn W., - He C., (2014): Rheological and mechanical properties of epoxy/clay nanocomposites with enhanced tensile and fracture toughnesses, Polymer (2014) 43-52. https://doi.org/10.1016/j.polymer.2014.12.042

[42] Wood-Adams, P. M. - Dealy, J. M. - deGroot, A. W. - Redwine, O. D. (2000): Effect of Molecular Structure on the Linear Viscoelastic Behavior of Polyethylene, Macromolecules 33 (2000) 7489-7499. https://doi.org/10.1021/ma991533z

[43] Wu, D. - Wu, L. - Sun, Y. - Zhang, M. (2007): Rheological properties and crystallization behavior of multi-walled carbon nanotube/poly( $(\mathbb{-}$ caprolactone) composites, Journal of Polymer Science: Part B: Polymer Physics 45 (2007) 3137-3147. https://doi.org/10.1002/polb.21309

[44] Zhang, X. - Yang, G. - Lin, J. (2006): Synthesis, Rheology, and Morphology of Nylon-11/Layered Silicate Nanocomposite, Journal of Polymer Science: Part B: Polymer Physics 44 (2006) 2161-2172. https://doi.org/10.1002/polb.20881

[45] Zhao, J. - Morgan, A. B. - Harris, J. D. (2005): Rheological characterization of polystyrene-clay nanocomposites to compare the degree of exfoliation and dispersion, Polymer 2005 8641-8660. https://doi.org/10.1016/j.polymer.2005.04.038

[46] Zhao, Y. - Huang, H.-X. (2008): Dynamic rheology and microstructure of polypropylene/clay nanocomposites prepared under Sc-CO2 by melt compounding, Polymer Testing 27 (2008) 129-134. https://doi.org/10.1016/j.polymertesting.2007.11.006

[47] Zhong, Y. - Zhu, Z. - Wang, S.-Q. (2005): Synthesis and rheological properties of polystyrene/layered silicate nanocomposite, Polymer 46 (2005). https://doi.org/10.1016/j.polymer.2005.02.014

[48] Lohse, DJ - Milner, ST - Fetters, LJ - Xenidou, M. - Hadjichristidis, N. Mendelson, RA. - Garcia-Franco, CA - Lyon, MK (2002): Well-defined, model long chain branched polyethylene. 2. melt rheological behaviour. Macromolecules 35:3066-3075 https://doi.org/10.1021/ma0117559

[49] Schulze, D. - Trinkle, S. - Mulhaupt, R. - Friedrich, C. (2003): Rheological evidence of modifications of polypropylene by $\beta$-irradiation. Rheol Acta 42:251-258 https://doi.org/10.1007/s00397-002-0282-7

[50] Trinkle, S. - Friedrich, C. (2001): Van Gurp-Palmen plot: a way to characterize polydispersity of linear polymers. Rheol Acta 40:322-328 https://doi.org/10.1007/s003970000137

[51] Trinkle, S. - Walter, P. - Friedrich, C. (2002): Van Gurp-Palmen plot II - classification of long chain branched polymers by their topology. Rheol Acta 41:103-113 https://doi.org/10.1007/s003970200010

[52] Van Gurp, M. - Palmen, J. (1998): Time-temperature superposition for polymeric blends. Rheol Bull 67:5-8

[53] Aklonis, JJ. - Macknight, WJ.: Introduction to viscoelasticity. New York: Wiley; 1983.

[54] Utracki, LA. (1999): Polymer blends handbook. Netherlands: Kluwer Academic Publishers

$\underline{\text { Ref.: }}$

Kracalik, Milan: New approach for investigation of reinforcement in polymer nanocomposites using oscillatory shear flow data Építőanyag - Journal of Silicate Based and Composite Materials, Vol. 70, No. 2 (2018), 42-47. p https://doi.org/10.14382/epitoanyag-jsbcm.2018.9 